\title{
The Experience of Culture: Approaches to an Ethnography of the Immediate in Complex Relations
}

\author{
BERNHARD TSCHOFEN \\ ISEK - Institute for Social Anthropology and Cultural Studies, \\ University of Zurich
}

\begin{abstract}
"Utopias, Realities, Heritages. Ethnographies for the 21st century" the theme of the 2015 SIEF conference calls for questions: Do any new challenges for ethnography even exist in the $21^{\text {st }}$ century? Has ethnography not always had to overcome contradictions between a utopian character of culture and the everyday? Beginning with a brief glance at the changes in European ethnology's conceptions of culture, this paper discusses themes and ways of studying corporeal and sensory practices in everyday culture. Studies from sport, tourism, and spatially connoted heritage commodities thereby function as examples for the discussion of approaches beyond an essentialization of the elementary.
\end{abstract}

Keywords: European ethnology, sensuous ethnography, body, heritage, knowledge

\section{WHY CULTURE (YET AGAIN)?}

Why culture? Why, yet again, culture? This is a valid question, which may be asked both from within the field as well as from more distant perspectives. Indeed, for those in other fields of scholarship, it may seem odd how regularly "culture" is mentioned in European Ethnology - maybe especially in the German speaking area. It is as though it remains unclear what in fact we are studying.

Veterinarians would hardly always talk about the species in general, physicians not about the human body, lawyers not about their concept of law, and even the social sciences are not struggling with definitions of society all time but are at the most targeting specific findings regarding social dynamics - which led to the well known diagnoses of society between "experience", "risk" and "multi option" we became aware in the last decades. In the disciplinary context we are working within we can't count on this implicitness - and the reason for that is among others a subject of the present article. 
Besides explaining concepts of culture, as European Ethnologists we often have to familiarize outsiders with our interests and methods so that they may discover that our preoccupation with the everyday and popular culture is not simply an outlet for personal inclinations. Rather, involvement in the topics and mentalities of that which we investigate is simultaneously both a challenge and an opportunity. Anyone who studies the culture of skiing or European cheeses, for example, is always viewed with a certain suspicion as they arguably risk exchanging personal interest for academic distance. I hope that the following insights into a couple of fields of study do not confirm these suspicions.

The title, "The Experience of Culture," serves as both a trivializing camouflage and an indication of a disciplinary discourse, which will, at least roughly, be outlined here. In the following five sentences or so I will attempt to recap nearly five decades of development in the field of European Ethnology and the terminology of culture. In other fields, new theories may be discovered by chance. This is not the case in the humanities, wherein they always indicate objective and subjective dynamics in society and culture (as well as in literature and language, etc.). That is, they respond to changes in their objects of study, and thus are themselves changed. Scholarly modes of thought and scholarship in the humanities are culturally situated and not to be conceived of in the same way at all times. Indeed, the post-war era introduced a momentous expansion of the concept of culture. This made Cultural Studies itself and its international success possible. In addition, and in the light of our traditional subjects, it also modernized Volkskunde, instigating a powerful shift from Volk (Folk) to culture and from Kunde (lore) to Wissenschaft in terms of, if not science, then at least scholarship. Since then, the field shares the broad anthropological concept of culture in various nuances. In addition to expanded Cultural Studies, these concepts have been largely appropriated by Ethnology and more recently, by anthropological approaches in historical scholarship. For the most part, this concept of culture differentiates itself from older understandings in the social sciences in that it does not reduce culture to a functional superstructure of society, but views it as a foundation and expression of the social world. Or, as it was casually and memorably signified in the objectives of the Tübingen program of Empirische Kulturwissenschaft in 1970, "culture as the other side of society" (Johler et al., eds 2013).

With this expansion, the field was able to secure its academic survival following the (also political) discretization of its object of study. However, this was also accompanied by an increasingly manifest problem, which lay in the holism of the anthropological concept of culture that is always necessarily in possession of homogenizing and in- and exclusionary dimensions: "We and the others." The success with which this new concept rapidly emerged 
on the heels of a (luckily!) never-to-be overcome crisis, had been spurred by the critique of representation and culturalism, and characterized by a variety of responses. These ranged from the consequential call for "writing against culture" (Abu-Lughod 2006), to an appeal for the more moderate task of continually reflecting upon culture as a concept of power. Those who signalled for vigilance could comfortably adopt a general understanding of the Bourdieuan concept of "culture as practice" as it had become common sense in the humanities at large (Bourdieu 1977).

Coupled with this - and applying directly to my generation's years of academic socialization - is a constructivist philosophy and approach, whose theoretical instruments are borrowed from the discourses and practicaltheoretical schemata of French Poststructuralism. This too is problematic, regardless of how much they may insist on their perspective of "doing culture," that is the degree to which they lose sight of essential dimensions of daily life. This is especially true when, as is the case in our late modern, complex everyday life - both thought and action - is framed by technologies and the media (Rabinow and Marcus 2008). More so than in the clear orders of previous generations, these inevitably reference institutionalized stocks of knowledge. It is here that cultural analysis of practice culminates all too quickly in a symbolic dimension of culture and displaces emphasis on nonintelligible experiences.

Thus, we arrive at a central contradiction: On the one hand, the emphasis on "doing culture" has strengthened the role of actors and experiential perspectives. However, the fear of essentialization seems to have restricted the analytical potential of European ethnology. In other words, the cardinal question of structure and process, and action ability must be repeatedly asked while potential conceptual answers are to be questioned and moreover, transferred to a micro perspective empiricism (cf. Ehn, Löfgren and Wilk 2015).

\section{CULTURE AS CORPOREAL AND SENSUAL PRACTICE}

Experiencing culture also means consciously not living culture. This is not a plea for vitalistic or holistic understandings which had to a large extent been overcome by the above mentioned critique of its inherent meanings. In the following and by way of a few select examples, I would in contrast like to demonstrate how people encounter culture in the broadest sense of the term in their daily lives. As my brief theoretical introduction has hopefully made clear (cf. Tschofen 2013b), I am not concerned with the reception of Culture with a capitalized "C," that which occurs in concert halls and the art museums of the world. Nevertheless, these too can be objects of popular culture and later, we will indeed return to the museum for a shirt visit. 
My first example is drawn from "Living History," a project that was funded by the Volkswagen foundation from 2011 to 2014 in Tübingen and consisted of a collaboration with historians and archaeologists. With a number of case studies, my colleagues and I examined how people practice history and which techniques they utilize in order to imbue these practices with a certain social beneficence and pleasure (Willner, Koch and Samida, eds. 2016). The truly astounding in our results is not how individual these adaptations are or how varying modes of historical didactics beget differing levels of participation. Instead, the most interesting aspect lay in the ways in which actors make use of their bodies as media for experience and especially, the multi-sensuality of the associated practices. In the course of this project, Sarah Willner produced a methodologically highly stimulating dissertation wherein she accompanied hikers on themed walks as they followed the trails of the glacier mummy, 'Ötzi 'Ötzi' (Willner 2016). These hikers utilized physical and material parallels to Bronze Age hunters in order to produce a corporeally experienced presence, thereby attempting to internalize an understanding of historical lifestyles. In his Phenomenology of Landscape, the British archaeologist, Christopher Tilley - a significant theorist of material culture studies (UCL) - described his notion of "similar bodies" (2004: 29). For us, this may be a rather dated concept, yet in the booming field of cultural history, it offers specific forms of what in knowledge research is referred to as "bodily knowledge" and indicates a knowledge released through corporeal practices.

As I recently returned to one of my older fields of research, which deals with historical accounts of popular mountain enthusiasm, I discovered a similar phenomenon in historic sources, mainly functional literature of Alpinism and tourism. By paying special attention to expressions of corporeal sensation beyond the dominant or superficial (which is perhaps more of a problem with research than with the sources themselves), it becomes clear that the use of the senses for the enhancement (or moderation) of experience in late $19^{\text {th }}$ century alpine tourism was both routinized and reflected-upon. This does not simply apply to the experience and adoption of an unfamiliar environment. Rather, it occurs in the relationship between "people and land" and in the promises, which were representative of a certain lifestyle and that were made to a milieu, which was world-weary and critical of society. In these accounts, the acts of listening and feeling on the mountain peak are described, the practices of loud singing against the mysterious sounds of the glacier, an unfamiliar movement is prized for its effects on the organs, and through experience, an experimentation with unknown smells and tastes takes place (Tschofen 2015).

"Tracks," our book on the culture of Alpine skiing, which we finished in 2014, provides another example of this concept (Dettling and Tschofen 2014). We ultimately found that the focus on techniques of movement on the 
one hand, and on infrastructure on the other, which has dominated sports and tourism history to date, has disguised a more proper approach focussing the relationship between sensual-corporeal experience and an image of winter sports as a program of modern self-efficacy. In order to expose this, it was necessary to consider the elementary practical relationship between the snowy slopes of the mountains and the social scene of the Hütten (mountain cabins), as well as the accompanying reflectivity, which was primarily related to the natural environment, to things and the body as media for experience.

The field of a historically thinking and arguing Cultural Anthropology or European Ethnology (cf. Scheer et al., eds 2013), thus occupies a unique position in its duties and functions. It has been given a task that simultaneously encompasses a vast methodological potential: To an extent, this is located between (present-oriented) social sciences and (historically-oriented) humanities and has the potential to transfer concepts from ethnographic analysis of the present to certain aspects of historical reality. This allows historical ethnography, or an actor-centred cultural analysis to become an object of research. Thus, we come into contact with the increasing efforts of historical anthropology in recent years to no longer understand the modelling of the senses (Howes, ed. 2005) as a history of loss, but as an aspect of the diverse negotiations of social orders and orientations in the social world (Pink 2010).

What I can only briefly outline here is certainly not limited - as my examples may suggest - to practices of tourism or heritage, but is indicative of a far more general pattern in popular culture. Those who enjoy watching television (or like myself, live with those who do) know that in such social situations we are capable of mobilizing that "cognitive style," which Kaspar Maase has argued "occurs without noticeable effort, without cumbersome concentration, without the laborious mobilization of knowledge" and allows for "feeling and thinking [to be] spurred in a comfortable physiological way" (Maase 2011: 287). In her dissertation on the German detectives series "Tatort" as a mediator of social positioning, Christine Hämmerling was able to further develop these approaches. Those who watch television together, for example, participate in an emotional community and through interaction within the group, construct an ambience or, respectively, an atmosphere, "which augments the experiential nature of the situation of viewing" (Hämmerling 2016: 132).

\section{ARRANGEMENT AND ORDER: CULTURAL SPACES}

The keyword "atmosphere" implies that when one speaks of an "experience of culture," it is associated with a concrete place or particular spaces in everyday culture. So too, outside of the popular concept of space as a more 
or less given order, this dimension is almost inevitable in cultural analysis. There are two reasons for this inevitability. First, it lies in the traditional and continuously widespread understanding that culture occurs in a space and is both spatially limited and experienced. Second, after a long period of spatial oblivion in the humanities (Soja 1989), space has become a central category of analysis in recent years. Contrary to popular and natural-scientific understandings of space, in the social world, space is not absolute or a mere abstraction, nor is it a container that reliably surrounds limitable realities. On the contrary, space (or rather, spatiality) is constituted only alongside other spaces; it is thus relational, not absolute. In addition, it is only conceivable as a relational space in conjunction with activity. That is, historical and social practices shape this space allowing it to become a material, inescapable reality, though this is always in relation to other spaces and moreover, to associated understandings.

Indeed, the relationship between cultural experience and spatiality is highly dualistic. This is because our reoccurring actions, based in understandings or concepts, figurate space just as they are made possible and limited by the objectification of these orders. Let me explain this by reference to spaces that are very familiar to our daily life in the academia. In the corridors and classrooms of our universities, a historical practice of knowledge is firmly situated. It allows for specific forms of speaking and listening, and excludes others. It does something habitual with us, positions us in an arrangement, which informs us of what to do and couples specific modes with perception and action.

I would like to return for a moment to spatial understandings in daily life, which I briefly mentioned above. In multiple works of scholarship on regionality - most recently in the newly completed research project of the German Research Foundation DFG on "geographical indications as cultural property" (May et al., eds 2016) - it has been possible to gain new insight into spatial politics and their relationship to the everyday experience of region. Our comparative case studies on the transformation of so-called culinary heritage to cultural property - so to speak "cheese studies" - have shown that the spatialities of European cheese specialities are in no way selfevident. Rather, they may be understood as the product of ongoing processes of negotiation. They become "commodity heritage" (Grasseni 2005: 83) through instruments of protection, associated practices of inclusion and exclusion (cf. Welz 2015), and narrative features and semantic differentiation. Yet they do not fall short of their potential effect as they consistently couple evidence of authenticity with the promise of an immediate experience of a spatially-situated tradition. In Switzerland, this ranges from a functional interconnection of the metropolitan areas with the mountainous regions, which may be understand as a novel form of "moral economy," (Green and Jenkins 2009: 214), and contributes significantly to the dominant notions of 
these spaces, which circulate in the general public. Recently a Zürich daily newspaper asked: "Is Grisons (from the eastern Swiss Alpine canton Grison) food the better food?" and by way of a series of examples, claimed "that the 'lowlanders' pounce on it" (Böniger 2015).

Published in the 1980s, Italo Calvino's Under the Jaguar Sun is a work of special interest for anthropologists of the senses as it narratively plays with a convergence of the five senses and provides a wonderful understanding of this concept of consumable culture:

The true journey, understood as an introjection of an "outside," different from our normal one, implies a complete change in nutrition, a digesting - its fauna and flora, and its culture (not only the different culinary practices and condiments but the different implements used to grind the flour or stir the pot) - making it pass between the lips and down the oesophagus. This is the only kind of travel that has meaning nowadays, when everything visible you can see on T.V. without rising from your easy chair. (Calvino 1988: 12)

What Calvino could not yet know, is how self-evident the simultaneous medial framing of the corporeal would become for us. Thus, I speak to what are most likely the two biggest challenges of an ethnography of the present. It is not without reason that they dominated the biennial conference of the Deutsche Gesellschaft für Volkskunde (dgv) 2015 in Zurich. "Cultures of the Senses" is one of the main topics of the Popular Cultures division of the ISEK - Institute for Social Anthropology and Cultural Studies at the University of Zurich. The conference deepened this field and the relevant interdisciplinary discourses of recent years. Among other goals it could aid in measuring the growing importance of technical and medial environments for everyday actions and sensual dimensions (Braun et al. eds, forthcoming).

Allow me to briefly provide an example of this research. In a proposed project on "Language and Space," which is part of the program for the Zürich URPP (University Research Priority Programs), we would like to examine the daily integration of augmented space. In this, we are primarily interested in the transition zones between virtual and real spaces, which can certainly no longer be conceived of as dichotomous, and the assumptive co-production of space in such technically and medially advanced environments. Indeed, thus far, we know very little about how actors deal with spatial usability cues, which make possible a spatial experience in varying environments, and more importantly, ready an expansion and intensification of experience. For this, representations (maps, digital guides, or other multi-media-based applications) are to be examined, as is how differing media are joined together and integrated into active practice. A core question is thus directed at the translatability between representations of "themed environments" and individualized conceptualizations of such spaces. 


\section{KNOWLEDGE AND PRACTICE: ENVIRONMENTAL EVIDENCE}

In my remarks thus far, I have attempted to indicate that the discourse on culture in European Ethnology is not only aimed at the "big picture." Indeed, it attempts to clarify this otherwise and continually nebulous central category of our thoughts and work through a situated confrontation with other analytical categories. Here - with one eye on the question of the experience of culture - space had to be mentioned. Thus knowledge, an indispensable category of both for our research in general, has been incorporated into my argumentation. The background for this is the anthropological concept of knowledge (cf. Barth 2002), wherein the transmission of knowledge is not to be understood merely as an interaction, but also its creation by different actors (people, but also objects, discourses, and media) is to be understood as a constructed process. Its goal is based more on practices, which we have seen are largely implicit, than on corpuses.

A place of knowledge - and of popular enjoyment - which incorporates each of these dimensions with its specifically modern and popular mode of showing and recognizing is the museum. Unfortunately, there is not enough space here to outline a genealogy of the modes of perception, which are coupled with museums and other places of cultural observance. In brief, however, this genealogy ranges from the aesthetic education of the Enlightenment, the ars apodemica of the $19^{\text {th }}$ century with their emphasis on techniques of historical and cultural experience, through the reform movements of the turn of the century, wherein notions of holism and sensual recognition were drawn upon and practical experience became a starting point for reflection and empowerment. Through local history scholarship and later, the reform of museums, these concepts were deeply connected to fields of historical knowledge transfer. Theoretical positions at this time indicate a similar direction. As early as 1886 in his dissertation, Prolegomena to a Psychology of Architecture, Heinrich Wölfflin asked: "How is it possible, that architectural forms may be an expression of a soul, a feeling?" (Wölfflin 1886: 1). So too, the Viennese art historian Alois Riegl made feeling and orders of living environments two cornerstones of his theory on monuments, which also hopes to be a theory of enthusiasm for the historical.

At this time, there was already an interest in things and their relationship to living environments, or the radiance of the historical, which Alois Riegl called the "Stimmungswert" ("mood value"). According to Riegl, the notion that man is categorized into universal orders, allows him to recognize in monuments a part of his own life (Riegl 1903). Similar notions were being simultaneously espoused by Georg Simmel, who spoke of a spiritual holism wherein the past and present merge in a unity of aesthetic enjoyment (Simmel 1914/15). 
To produce this relationship between experience and one's own life is a cultural technique, which has in many ways been educated by modernity. There are instructions for this, which understand its medial representation and which we have, in terms of emotion and cognition, mastered through habituated practice. The production and experience of evidence are of central importance. So too, aspects of performativity, that is, the forms and modi of validating and highlighting something through activity, seem to be essential. In this context, the Swiss historian Valentin Groebner has aptly referred to a "post-production of the past" (Groebner 2013).

This also makes contemporary actors experts in the authentic; they are competent in their mastery of techniques of corporeality and perception, which highlight and provide evidence for contexts of ambience. Benno Gammerl and Monique Scheer proposed the concept of "emotional styles" (Gammerl 2012) to refer to this competency. Emotional styles include varying modes of thinking about, cultivating, handling, and expressing feeling. The concept is drawn from Bourdieu's concept of the habitus, but is focused on emotions (cf. Scheer 2012). I believe that this concept may be made fruitful for an "emotional knowledge of the cultural", if I may be so vague in my formulation. This emotional knowledge of the cultural alludes to the notion that ideas and experiences remain largely implicit and are thus ascribed to tacit knowledge. At the same time, such knowledge is highly situational, it is inscribed not only in and on the body, but lies in relationships which enter into its materially and medially communicated environments.

Knowledge circulation in the fields of culture not only draws from the transferral relationships between theory and practice, and academia and various publics; it may be found in the associations - assemblages in the sense of the ANT - between human body and the material and spatial environment (Latour 1993). The co-presence of actors and non-human actants - be it in historical play, in a conditioned world heritage site, or in a museum - produces experience and in this way, allows for the adoption of the implicit in spaces and acts. The experience of culture in the everyday, may be understood in Don Ihde's terms as "material hermeneutics," wherein things and places participate in the co-construction of recognition (Ihde 2005).

\section{PROSPECTS: ETHNOGRAPHIC RECOGNITION AND EVERYDAY LIFE}

In my examples and remarks presented above I have deliberately not drawn clear dividing lines between daily and institutionalized, and popular and scientific practices of knowledge. On the contrary, I have consciously at- 
tempted to blur these boundaries. This was done not only out of respect for the expertise of the many and with one eye on the processes of transcending boundaries in our knowledge community, but also to draw attention to a specific epistemic constellation. Our field, more than any other, is deeply connected to its own subject matter, not only because we share the origin of our ways of thinking with the "cultures" we study (cf. Tschofen 2013a), but also because daily practices play an important role in our empiricism and vice versa. Thus, it is not only about understanding the everyday world in which people move, but also the conditions and effects of our ethnographic production of knowledge. As consumers of culture (a term that I have thus far avoided), we seek impressive encounters and experiences in our own cognitive processes. This is not only unavoidable, but also necessary and involves ourselves and our bodies as media of experience (cf. Pink 2010).

Perhaps I may conclude by returning to a reference that was made, but not expanded upon above. The intensified discourse on ambience, which has drawn upon Gernot Böhme's new aesthetics (Böhme 1995), provides a tempting approach for the humanities. Nevertheless, it is concerned, as we must so often recognize, with a concept that though it is theoretically convincing, it is difficult to operationalize on a methodical level. Indeed, it loses its significance as soon as one begins to ask for the practical dimensions within highly resolved empirical work. In other words - and in brief - if cultural analysis of the everyday wants to avoid limiting itself to representations, symbolic forms, and intellectual practices, it also must not omit a clarification or sharpening of those concepts and methods, which productively couple phenomenological and praxeological modes of access in order to make concepts more concrete and methodologically accessible.

\section{REFERENCES AND SOURCES}

Abu-Lughod, Lila. 2006. "Writing Against Culture". In Feminist Anthropology. A Reader. Ellen Lewin, ed. Malden: Blackwell anthologies in social and cultural anthropology 8: 466-479.

Barth, Fredrik. 2002. "An Anthropology of Knowledge". Current Anthropology 42/1: 1-18. [http://dx.doi.org/10.1086/324131]

Böhme, Gernot. 1995. Atmosphäre. Essays zur neuen Ästhetik. Frankfurt a.M.: Suhrkamp.

Bourdieu, Pierre. 1977. Outline of a Theory of Practice. Cambridge: Cambridge Univ. Press. [http://dx.doi.org/10.1017/CB09780511812507]

Braun, Karl, Claus-Marco Dietrich, Thomas Hengartner and Bernhard Tschofen, eds. 2017. "Kulturen der Sinne. Zugänge zur Sensualität der sozialen Welt" (40. Kongress der Deutschen Gesellschaft für Volkskunde, Zürich 2011). Münster et al.: Waxmann [publ. in preparation].

Böniger, Daniel. 2015. “Ist Bündner Kost die bessere Kost?” Tagesanzeiger 27 February 2015. Calvino, Italo. 2002. Under the Jaguar Sun (1988). London: Vintage. 
Dettling, Sabine and Bernhard Tschofen. 2014. Tracks. The Arlberg and the Culture of Skiing. Bregenz: Bertolini.

Ehn, Billy, Orvar Löfgren and Richard Wilk. 2015. Exploring Everyday Life. Strategies for Ethnography and Cultural Analysis. Lanham: Rowman \& Littlefield.

Gammerl, Benno. 2012. "Emotional Styles - Concepts and Challenges". Rethinking History 16/2: 161-175. [http://dx.doi.org/10.1080/13642529.2012.681189]

Grasseni, Cristina. 2005. "Slow Food, Fast Genes. Timescapes of Authenticity and Innovation in the Anthropology of Food". Cambridge Anthropology 25/2: 79-94.

Green, Joshua and Henry Jenkins. 2009. "The Moral Economy of Web 2.0". In Media Industries. History, Theory and Method. Jennifer Holt and Alisa Perren, eds. Malden: Wiley-Blackwell, 213-225.

Groebner, Valentin. 2013. "Touristischer Geschichtsgebrauch. Über einige Merkmale neuer Vergangenheiten im 20. und 21. Jahrhundert". Historische Zeitschrift 296: 408-428. [http://dx.doi.org/10.1524/hzhz.2013.0103]

Gumbrecht, Hans Ulrich. 2011. Stimmungen lesen. Über eine verdeckte Wirklichkeit der Literatur. München: Carl Hanser.

Hämmerling, Christine. 2016. Sonntags 20:15 Uhr - Tatort. Soziale Positionierungen eines Fernsehpublikums. Göttingen: Studien zur Kulturanthropologie / Europäischen Ethnologie, 5.

Howes, David, ed. 2005. Empire of the Senses. The Sensual Culture Reader. Oxford, New York: Berg.

Ihde, Don. 2005. "More Material Hermeneutics”. Yearbook of the Institute for Advanced Studies on Science, Technology and Society. München, Wien: Profil, 341-350.

Johler, Reinhard, Christian Marchetti, Bernhard Tschofen and Carmen Weith, eds. 2013. Kultur_Kultur. Denken. Forschen. Darstellen (38. Kongress der Deutschen Gesellschaft für Volkskunde, Tübingen 2011). Münster et al.: Waxmann, 38-48.

Latour, Bruno. 1993. We Have Never Been Modern. Cambridge, Mass.: Harvard Univ. Press.

Maase, Kaspar. 2011. Das Recht der Gewöhnlichkeit. Über populäre Kultur. Tübingen: Untersuchungen des Ludwig-Uhland-Instituts der Universität Tübingen, 111.

May, Sarah, Katia L. Sidali, Achim Spiller and Bernhard Tschofen, eds. 2016. Taste - Power Tradition. Geographical Indications as Cultural Property. Göttingen: Studien zu Cultural Property, 11 [in print].

Pink, Sarah. 2010. "Principles for Doing Sensory Ethnography. Perception, Place, Knowing, and Imagination". In Doing Sensory Ethnography. London, Los Angeles: Sage, 23-43.

Rabinow, Paul and Gorge E. Marcus. 2008. Designs for an Anthropology of the Contemporary. Durham et al.: Duke Univ. Press. [http://dx.doi.org/10.1215/9780822390060]

Riegl, Alois. 1903. Der Moderne Denkmalkultus. Sein Wesen und seine Entstehung. Wien, Leipzig: Braumüller.

Scheer, Monique. 2012. "Are Emotions a Kind of Practice (and What is That What Makes Them Have a History)? A Bourdieuan Approach to Defining Emotion". History and Theory 51/2: 193-220. [http://dx.doi.org/10.1111/j.1468-2303.2012.00621.x]

Scheer, Monique, Thomas Thiemeyer, Reinhard Johler and Bernhard Tschofen, eds. 2013. Out of the Tower. Essays on Culture and Everyday Life. Tübingen: Untersuchungen des LudwigUhland-Instituts der Universität Tübingen, 114.

Simmel, Georg. 1914/15. "Rembrandtstudie”. LOGOS. Internationale Zeitschrift für Philosophie und Kultur 5/1: 1-32.

Soja, Edvard. 1989. Postmodern Geographies. The Reassertion of Space in Critical Social Theory. London: Verso. 
Tilley, Christopher. 2004. The Materiality of Stone. Explorations in Landscape Phenomenology. Oxford, New York: Berg.

Tschofen, Bernhard. 2013a. "Selbstbeschreibungen beschreiben? Zur Kulturanalyse des Kulturgebrauchs". In Kultur_Kultur. Denken. Forschen. Darstellen (38. Kongress der Deutschen Gesellschaft für Volkskunde, Tübingen 2011), Reinhard Johler et al., eds. Münster et al.: Waxmann, 38-48.

Tschofen, Bernhard. 2013b. "On Everyday Life. Fates of the Obvious in European Ethnology". In Out of the Tower. Essays on Culture and Everyday Life. M. Scheer et al., eds. Tübingen: Untersuchungen des Ludwig-Uhland-Instituts, 114, 72-83.

Tschofen, Bernhard. 2015. [3312] Piz Buin. Litererarische Erkundungen 1865-2015. Bregenz: Bertolini.

Welz, Gisela. 2015. European Products. Making and Unmaking Heritage in Cyprus. Oxford, New York: Berghahn.

Willner, Sarah. 2016. Geschichte en passant. Archäologisches Themenwandern in den Alpen als wissens kulturelle Praxis. Tübingen: Univ. Diss. [publ. in preparation].

Willner, Sarah, Georg Koch and Stefanie Samida, eds. 2016. Doing History. Performative Praktiken in der Geschichtskultur. Münster et al.: Waxmann/Edition Historische Kulturwissenschaften, 1 [in print].

Wölfflin, Heinrich. 1886. Prolegomena zu einer Psychologie der Architektur. München: Univ. Phil.Diss, C. Wolf \& Sohn.

\section{ISKUSTVO KULTURE: PRISTUPI ETNOLOGIJI BLISKOGA U KOMPLEKSNIM ODNOSIMA}

Naslovna tema konferencije SIEF-a iz 2015. godine “Utopije, realnosti, baštine. Etnografije za 21. stoljeće” priziva niz pitanja: Zašto je noviji diskurs europske etnologije u tolikoj mjeri usmjeren na koncept baštine? Na što se odnose nazivi predstavljeni u naslovu programa tog skupa? Postoje li baštine i izvan okvira realnog i utopijskog karaktera kulture? Rad započinje kratkim opisom razvoja koncepta kulture u europskoj etnologiji, a zatim se u njemu raspravlja o jedinstvenim izazovima etnologije kasnog modernog razdoblja, koja je ukotvljena u kompleksnim konstelacijama i koja je u temelju usredotočena na sudionika. U radu se pokazuje da etnografija koja se bavi tjelesnim i osjetilnim praksama i koja je podložna uvjetima globalizacije i okoline posredovane tehnologijom otvara vrata pristupima koji nadvladavaju esencijalizaciju elementarnoga. $U$ tu se svrhu prikazuju istraživanja koja proučavaju odnos između ljudi i njihove okoline, njihovih mentalnih krajolika i smještene drugosti, oprimjeren u susretima s prirodom kroz sport, turizam i baštinu kao robu. U zaključku, na temelju paralela etnografskih susreta i svakodnevnog iskustva i percepcije, pokušava se dati jedna perspektiva na specifični potencijal i poteškoće rada u našoj disciplini danas.

Ključne riječi: europska etnologija, etnografija percepcije, tijelo, baština, znanje 